\title{
A STUDY ON CORROSION OF PAINT-COATED STEEL WITH DEFECTS IN MARINE ENVIRONMENT
}

\author{
Nobuaki OTSUKI ${ }^{1}$, Aung Kyaw MIN ${ }^{2}$, Marish MADLANGBAYAN³ \\ and Takahiro NISHIDA 4 \\ ${ }^{1}$ Member of JSCE, Professor, Dept. of International Development Engg., Tokyo Institute of Technology \\ (S6-11, 2-12-2, Ookayama, Meguro-ku, Tokyo 152-0033, Japan) \\ E-mail:otsuki.a.aa@m.titech.ac.jp \\ ${ }^{2}$ Engineer Trainee, Chiyoda Corporation \\ (Rm.804, Arumoni Tennochou, Hodogaya-ku, Nishi kubo-cho 16, Yokohama 240-0022, Japan) \\ E-mail: makyaw@ykh.chiyoda.co.jp \\ ${ }^{3}$ Doctoral Degree Student, Dept. of International Development Engg., Tokyo Institute of Technology \\ (S6-11, 2-12-2, Ookayama, Meguro-ku, Tokyo 152-0033, Japan) \\ E-mail: madlangbayan.m.aa@m.titech.ac.jp \\ 4 Member of JSCE, Engineer / Researcher, Center Research Institute for Electric Power Industry \\ (1646 Abiko, Abiko-shi, Chiba 270-1194, Japan) \\ E-mail: takahiro@criepi.denken.or.jp
}

\begin{abstract}
This paper presents the results of the laboratory investigations on the corrosion of paint-coated steel plates with defects under laboratory conditions of simulated marine environment and in the field. First, experimental qualitative evidence showing significant similarity of the polarization behavior between divided, which were used for measurement of each potential and macrocell current, and undivided steel plates was established. Macrocell and microcell corrosion were then monitored in paint-coated steel plates with defects under different exposure situations and temperatures. Lastly, corrosion rates in an existing paint coated steel structure in the field were estimated. Results show that values of electro-chemical measurements in divided steel plates are almost the same and showed the same trend as the undivided steel plate. Macrocell corrosion occurred between the painted part and the defect part of the steel plates. The exposure condition where high oxygen supply and high temperature exist, provided the most severe environment for corrosion of paint coated steel with defect. Moreover, corrosion rates in an existing steel structure in the field were successfully estimated.
\end{abstract}

Key Words : divided steel plates, undivided steel plates, defects, microcell corrosion, macrocell corrosion, paint coated steel

\section{INTRODUCTION}

Steel structures reach long and durable service lives when the surfaces of these structures are treated by application of protective coating of which the most common type is paint coating ${ }^{1), 2}$. In steel structures exposed to marine environment, paint coating is considerably effective as it can protect and slow down the corrosion of steel which is the main cause of the deterioration of steel structures. It protects the steel by (1) preventing the penetration of corrosion generative substances $\left(\mathrm{Cl}^{-}, \mathrm{H}_{2} \mathrm{O}, \mathrm{O}_{2}\right)$ and (2) providing a high resistant media between the cathode and anode area where a corrosion cell is formed on the surface ${ }^{3)-7)}$.

Defects in the paint coating of the structure due to mechanical and chemical causes cannot be avoided. Weak or defective areas on the paint coating may occur at the corners, edges or other places that are difficult to paint. Once the defect on the paint coating has occurred, corrosion generative substances can easily reach the steel and the corrosion process occurs. After corrosion is instigated, the process can then be controlled or accelerated by external influential factors including temperature and exposure situation. 


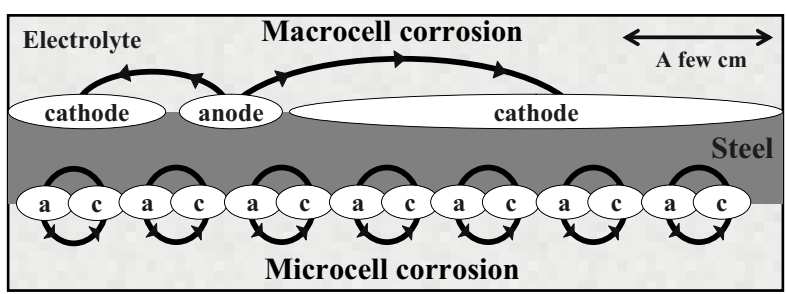

Fig. 1 Macrocell and Microcell corrosion.

The basic concepts of microcell and macrocell corrosion (Fig. 1) are important factors in the study of the corrosion behavior in paint-coated steel plates with defects. Microcell corrosion is the type of corrosion in which the anode and the cathode are adjacent to each other in a microscopic scale. This type of corrosion occurs uniformly throughout the surface of the metal. On the other hand, macrocell corrosion is the type of corrosion in which the anode and the cathode are physically separated by some finite distance away from each other on the metal surface. This type of corrosion takes place when the exposure of the metal surface is non-uniform. Using these two concepts, the influence of defects on the corrosion mechanism can be clearly presented.

In this study, the method of using divided steel plates to measure and monitor the macrocell as well as microcell corrosion on paint coated steel plates with defect was proposed. Using this proposed method, it is possible to measure the current flowing between the individual steel elements and it also allows for the identification of the cathodic and anodic areas of the macrocell conveniently using an ammeter ${ }^{8}$. Furthermore, divided steel plates can behave as undivided steel plates once the lead wires attached to the elements are all connected. However, a qualitative comparison of the corrosion behavior with undivided steel plates has not been made. In this study, experimental evidence for validating the proposal of using divided steel plates as a method to measure corrosion in normal or undivided steel plates was produced. Also investigation was done on the corrosion of paint coated steel plates with defects under different exposure situations and temperature conditions. The investigation was then extended to the estimation of corrosion rates in existing structures in the field.

\section{OBJECTIVES}

From the backgrounds mentioned above, the objectives of this study are as follows: (1) to propose the divided steel plate evaluation method for a detailed investigation of macrocell \& microcell corrosion in steel plate (2) to investigate the corrosion mechanism of paint-coated steel with
Table 1 Chemical composition and physical property of steel.

\begin{tabular}{|c|c|c|c|c|c|c|}
\hline $\begin{array}{c}\mathrm{Fe} \\
(\%)\end{array}$ & $\begin{array}{c}\mathrm{C} \\
(\%)\end{array}$ & $\begin{array}{c}\mathrm{Si} \\
(\%)\end{array}$ & $\begin{array}{c}\mathrm{Mn} \\
(\%)\end{array}$ & $\begin{array}{c}\mathrm{P} \\
(\%)\end{array}$ & $\begin{array}{c}\mathrm{S} \\
(\%)\end{array}$ & $\begin{array}{c}\text { Yield Strength } \\
\left(\mathrm{N} / \mathrm{mm}^{2}\right)\end{array}$ \\
\hline 99.28 & 0.16 & 0.02 & 0.45 & 0.013 & 0.06 & 295 \\
\hline
\end{tabular}

defects exposed to marine environment (3) to investigate the influence of exposure situations and temperature on corrosion of paint coated steel plates with defect and (4) to propose an estimation method for macrocell corrosion rate in existing structures.

\section{SCOPE OF EXPERIMENTAL WORK}

There are four groups of experiments conducted in this study. The first group qualitatively validates the proposal of using divided steel plates as a method to measure corrosion in normal or undivided steel plates. Corrosion polarization behavior including the half-cell potential and polarization resistance for both divided and normal steel plates were compared. The second group of experiments investigates the corrosion of paint coated steel plates with different types of defects using the method of divided steel plates mentioned above. The third group investigates the corrosion of paint coated steel plates with defects under different exposure conditions and temperature. The fourth group investigates the corrosion in an existing steel structure by estimating the macrocell and microcell corrosion rates using a proposed corrosion circuit model.

\section{EXPERIMENTAL OUTLINE}

\section{(1) Materials and specimen preparation}

The specimens used in the experiments were made of steel, the chemical composition and physical property of which are shown in Table 1. In this study, two types of specimens were mainly used, divided and undivided steel plates.

The divided steel plate was fabricated using an assembly of 9 steel elements each having a dimension of $1 \mathrm{~cm} \times 1 \mathrm{~cm} \times 0.5 \mathrm{~cm}$. Four lead wires were connected separately to each steel element by soldering. Slow curing epoxy was then used to bond (spacing was $0.1 \mathrm{~cm}$ ) the steel elements into a unit of $3 \mathrm{~cm} \times 3 \mathrm{~cm}$ divided steel plate (Fig. 2). All steel elements, except the middle steel element, were then connected to each other using the lead wires. Thus the divided steel plate is effectively composed of the middle steel element and the wire connected surrounding steel elements. The surface of the divided steel plate was then polished using a fine abrasive paper to obtain a smooth and level surface. 


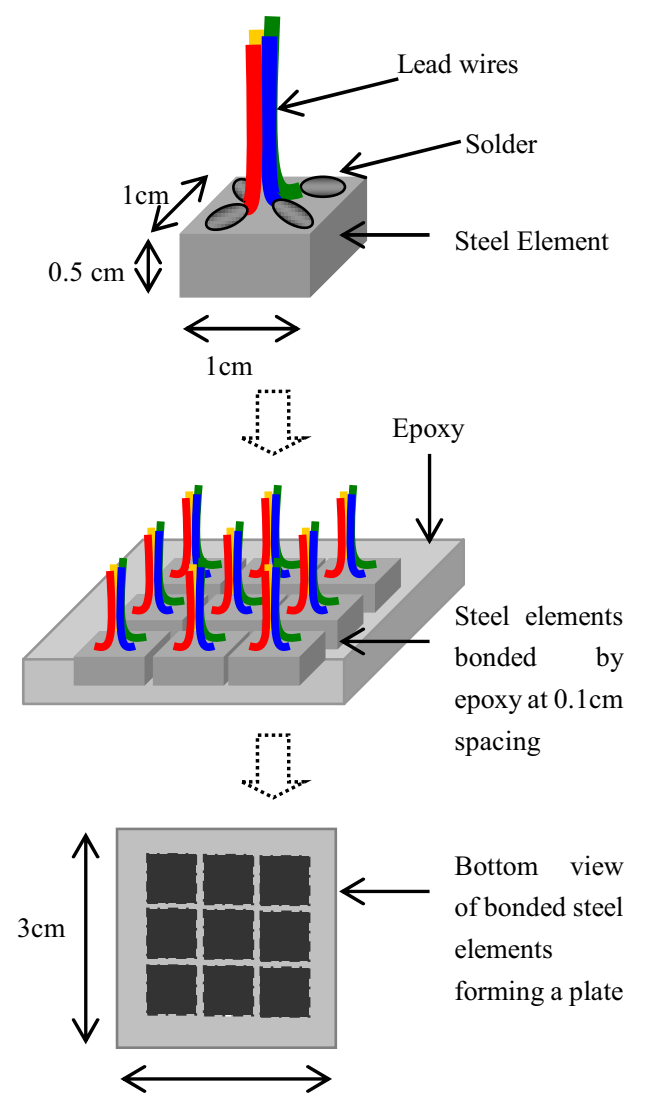

Fig. 2 Outline of divided steel plate.

On the other hand, undivided steel plates made of solid $3 \mathrm{~cm} \times 3 \mathrm{~cm} \times 0.5 \mathrm{~cm}$ steel and having the same composition as that in the divided form were fabricated in order to perform a comparative study between divided and undivided steel plates.

All the specimens were brush painted with paint (JIS K-5621 standard oil alkyd resin base paint) for general corrosion except for the specimens that will be used for proposing the method of using divided steel plates. The paint condition was set into two types; good and poor conditions that are mainly distinguished by the thickness of the coating. The paint coating thickness are $(138-188 \mu \mathrm{m})$ for good paint and $(45-65 \mu \mathrm{m})$ for poor paint.

\section{(2) Test Procedure}

a) Proposal of divided steel plate (to prove the similarity between divided and undivided plates)

In this experiment, the bare divided and undivided steel plates were submerged in $3 \% \mathrm{NaCl}$ solution under the same condition. The specimens were submerged in the $3 \% \mathrm{NaCl}$ solution in order to make a close simulation of the marine environment. The corrosion polarization behaviors of the two steel plates were then compared every week until 1-month.

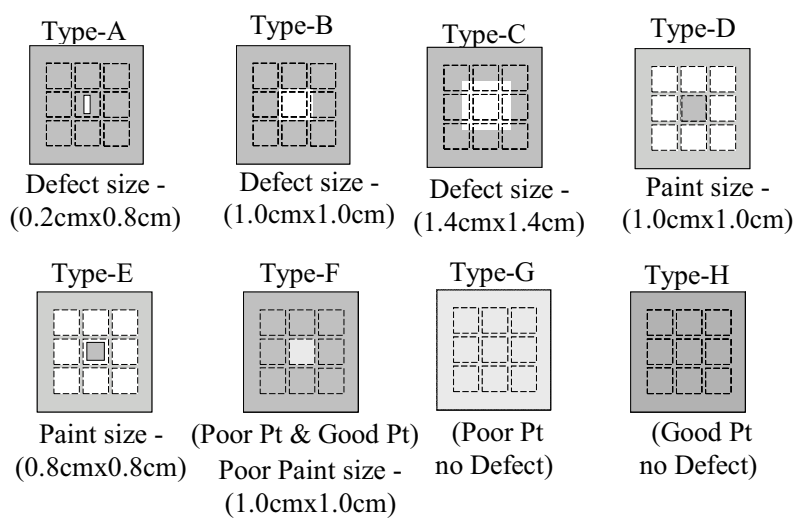

Fig. 3 Painted divided steel plates with defects.

\section{b) Investigation of the corrosion mechanism of paint-coated steel plate with defects}

In order to investigate the corrosion mechanism of paint-coated steel plate with defects, the painted divided steel plates with different types of defect (unpainted part) in the middle steel element were submerged in $3 \% \mathrm{NaCl}$ solution. The corrosion behavior of the specimens was investigated every month until 4-months. The details of the defect types are shown in Fig. 3

\section{c) Investigation of the influence of exposure situations}

In this experiment, the type-B specimens were exposed to different exposure situations such as vacuum, submerged, air-bubble, wet/dry and atmosphere situations. In the vacuum situation, (simulation of deep submerged exposure condition), the dissolved oxygen (D.O.) in $3 \% \mathrm{NaCl}$ solution was reduced to under $1.0 \mathrm{mg} / \mathrm{L}$ by using a vacuum pump. In the air-bubble situation, air-bubbles were supplied into the solution near the surface of the specimens at a rate of $10 \mathrm{~cm}^{3} / \mathrm{sec}$ using an air pump. In the wet/dry situation, the specimens were first exposed in $3 \% \mathrm{NaCl}$ solution same as the submerged situation for 1-day (wet situation). The solution was then removed and the setup was placed in an environment controlled chamber for 1-day (dry situation). For the atmosphere situation, the specimens were sprayed with $3 \% \mathrm{NaCl}$ solution everyday and then placed in an environment controlled chamber. The temperature was kept constant at $20^{\circ} \mathrm{C}$ and the corrosion behavior of the specimens was investigated every month until 4 months.

d) Investigation of the influence of temperature

The specimens under the situations of submerged, air-bubble and wet part of the wet-dry cycle were exposed to temperature controlled solutions $(20,30$ and $40^{\circ} \mathrm{C}$ ) using automatic heaters. On the other hand, the specimens under the situations of atmospheric and dry part of the wet/dry cycle were placed in an 
environment controlled chamber where the temperature was set to the same settings of 20,30 and $40^{\circ} \mathrm{C}$. The corrosion behavior of the specimens was then investigated every month until 4 months.

\section{(3) Investigation items}

\section{a) Polarization behavior}

The factors expressing polarization behavior such as halfcell potential and polarization resistance were measured using a corrosion monitor with $50 \mathrm{mV}$ of voltage supply and an amplitude ranging from 0.05 $\mathrm{Hz}$ to $5000 \mathrm{~Hz}$ as shown in Fig. 4.

The halfcell potential was measured with respect to $\mathrm{Ag} / \mathrm{AgCl}$ reference electrode and it was considered as a factor showing the possibility of corrosion in the steel. The polarization resistance was measured because it can describe the corrosion rate of the metal substrate. The polarization resistance is inversely proportional to the microcell corrosion rate. Thus the polarization resistance can be used to calculate the microcell corrosion current density as will be shown later.

\section{b) Macrocell corrosion rate}

Macrocell corrosion refers to the corrosion cell in which the anode and the cathode are physically separated along the surface of the steel plate. The macrocell corrosion current was measured between the middle steel element and the surrounding steel elements using zero resistance ammeters as shown in Fig. 5.

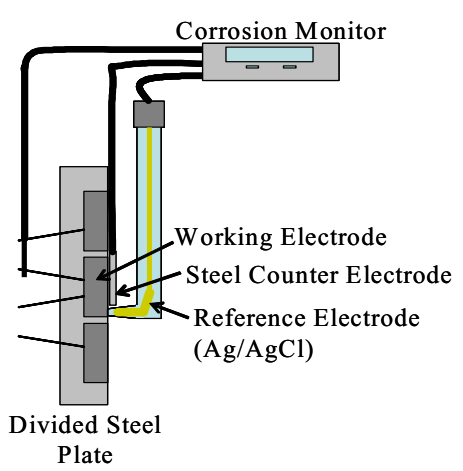

Fig. 4 Measurement setup of halfcell potential and polarization resistance.

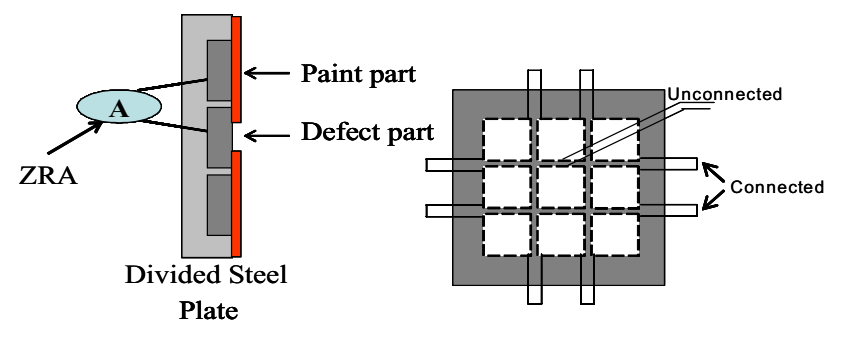

Fig. 5 Measurement setup of macrocell corrosion.
The macrocell current density was then calculated by using eq. (1).

$$
I_{m a c}=\frac{I}{S}
$$

where:

$I_{\text {mac }}$ : macrocell corrosion current density $\left(\mathrm{A} / \mathrm{cm}^{2}\right)$

$S$ : surface area of steel element $\left(\mathrm{cm}^{2}\right)$

I: current flowing between the middle and surrounding steel elements (A)

\section{c) Microcell corrosion rate}

Microcell corrosion refers to the corrosion cell in which the anode and the cathode are in the same physical location within the steel plate element. The microcell corrosion rate in steel can be determined based on its polarization resistance. Thus the microcell corrosion current density was calculated by substituting the polarization resistance reading obtained from the corrosion monitor device into eq. (2).

$$
I_{\text {micro }}=\frac{K}{R_{P} S}
$$

where:

$I_{\text {micro }}$ : microcell corrosion current density $\left(\mathrm{A} / \mathrm{cm}^{2}\right)$

$K:$ constant $=0.0209(\mathrm{~V})^{9)}$

$R_{P}:$ polarization resistance $(\Omega)$

$S$ : surface area of steel element $\left(\mathrm{cm}^{2}\right)$

The microcell and macrocell current densities were converted into corrosion rates by using the conversion factor $\left(100 \mu \mathrm{A} / \mathrm{cm}^{2}=1.16 \mathrm{~mm} / \text { year }\right)^{9)}$.

d) Calculation of steel mass loss by corrosion

The corrosion rate measured at each month was first converted to $\mathrm{g} / \mathrm{cm}^{2} /$ year. The steel mass loss at each month by macrocell $\&$ microcell corrosion was then calculated by multiplying the converted values $\left(\mathrm{g} / \mathrm{cm}^{2} /\right.$ year) with the exposure time (converted in years). The summation of the mass loss for each month until a 4 month period was then taken.

\section{RESULTS AND DISCUSSION}

\section{(1) Proposal of divided steel plate}

The average halfcell potential and polarization resistance at different measurement points on the surface of the divided and undivided steel plates were determined and compared until 4 weeks as shown in Fig. 6. From the results, it was confirmed that the halfcell potential and polarization resistance of the divided steel plate was almost the same as that of the undivided steel plate and indicated that the possibility and formation of corrosion reaction on 

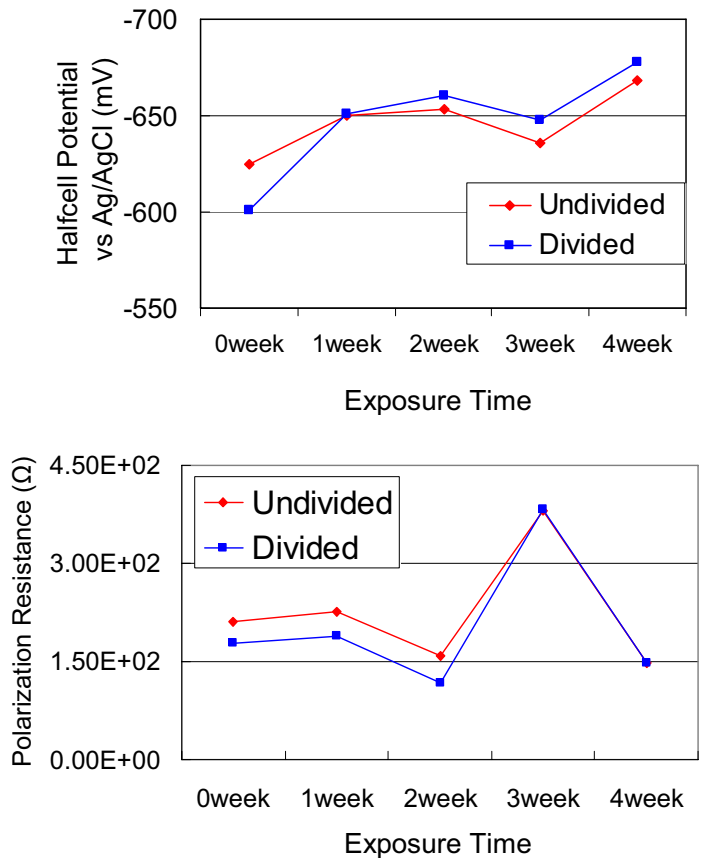

Fig. 6 Halfcell potential \& polarization resistance in divided and undivided steel plates.

divided steel plate was the same as that of the undivided steel plate. Therefore, it can be concluded that the divided steel plate can be used to investigate the corrosion behavior of undivided or normal steel plate and the proposal of using the method of divided steel plate in the evaluation of macrocell corrosion in steel plates was a success.

\section{(2) Investigation of the corrosion behavior of paint-coated steel with defects}

The results of the macrocell corrosion current density measured between the defect element and the surrounding painted steel elements of divided steel plates with the different types of defects are shown in Fig. 7. From the results, it was confirmed that the macrocell occurred between the defect and the surrounding painted part. The defect part acted as the anode while the surrounding paint part acted as the cathode. The defect part that was directly exposed to the salt solution (had no protective paint coating paving way for the occurrence of an easy dissolution of $\mathrm{Fe}$ ions) acted as the anode. On the other hand, the surrounding painted part or regions acted as the cathode mainly due to the presence of oxygen and water that have penetrated through the steel-paint interface by diffusion. In the type-F specimen, macrocell corrosion was also detected to occur between the good and the poorly painted parts. The part coated with poor paint acted as the anode and part coated with good paint acted as the cathode. There was almost no macrocell corrosion that occurred in the cases of paint coating without defect
(Type-G \& H). Therefore, it is noteworthy to say that the defect part in the paint coating was the main cause of macrocell corrosion. In defect type-A, B and $\mathrm{C}$ specimens, it was noted that as the size of the defect increased, macrocell current density also increased especially at the latter stages of exposure.

The microcell corrosion current density of the painted specimens with defects is shown in Fig. 8 . From the results, it was confirmed that microcell mainly occurred at the specimens with defects. The Type F specimens' poorly painted part showed higher microcell current density than the good painted part. This observation can be clearly seen at the latter stages of exposure. The specimens without any defect (Type-G \& H) exhibited very low microcell corrosion rates even when the 4 month period was already reached. Therefore, it can be concluded that the defect part was also the cause of microcell corrosion in paint-coated steel plates.

\section{(3) Influence of exposure situations and tem- perature}

The calculated steel mass loss by macrocell and microcell of the good painted type-B specimen are shown in Fig. 9. From the results, it was confirmed that the calculated steel mass loss in the specimens by macrocell and microcell corrosion was influenced by the exposure situation. The key factor for the influence of exposure situation was the dissolved oxygen content in the solution. The vacuum situation in which the dissolved oxygen was low gave the lowest calculated steel mass loss by macrocell and microcell corrosion. In the air-bubble situation which had high dissolved oxygen content, the calculated mass loss by macrocell and microcell corrosion was relatively high. Although the wet/dry situation showed the highest calculated steel mass loss by microcell corrosion, the macrocell corrosion for it was low. Therefore it can be concluded that the air-bubble situation was the most severe exposure situation for macrocell and microcell corrosion in paint-coated steel.

In order to investigate the influence of temperature, the calculated mass loss at the defect by macrocell and microcell corrosion under wet/dry, bubbles and submerged conditions at different temperatures were compared. Although it is expected that higher temperatures will yield higher corrosion rates and therefore increased mass loss, this trend might not be the same in certain situations.

From Fig. 10, it was confirmed that under wet/ dry condition and the condition with bubbles, as the temperature was increased, the calculated steel mass loss by macrocell and microcell corrosion also increased. This is due to the fact that increase in temperature increases the rate of corrosion reaction. 

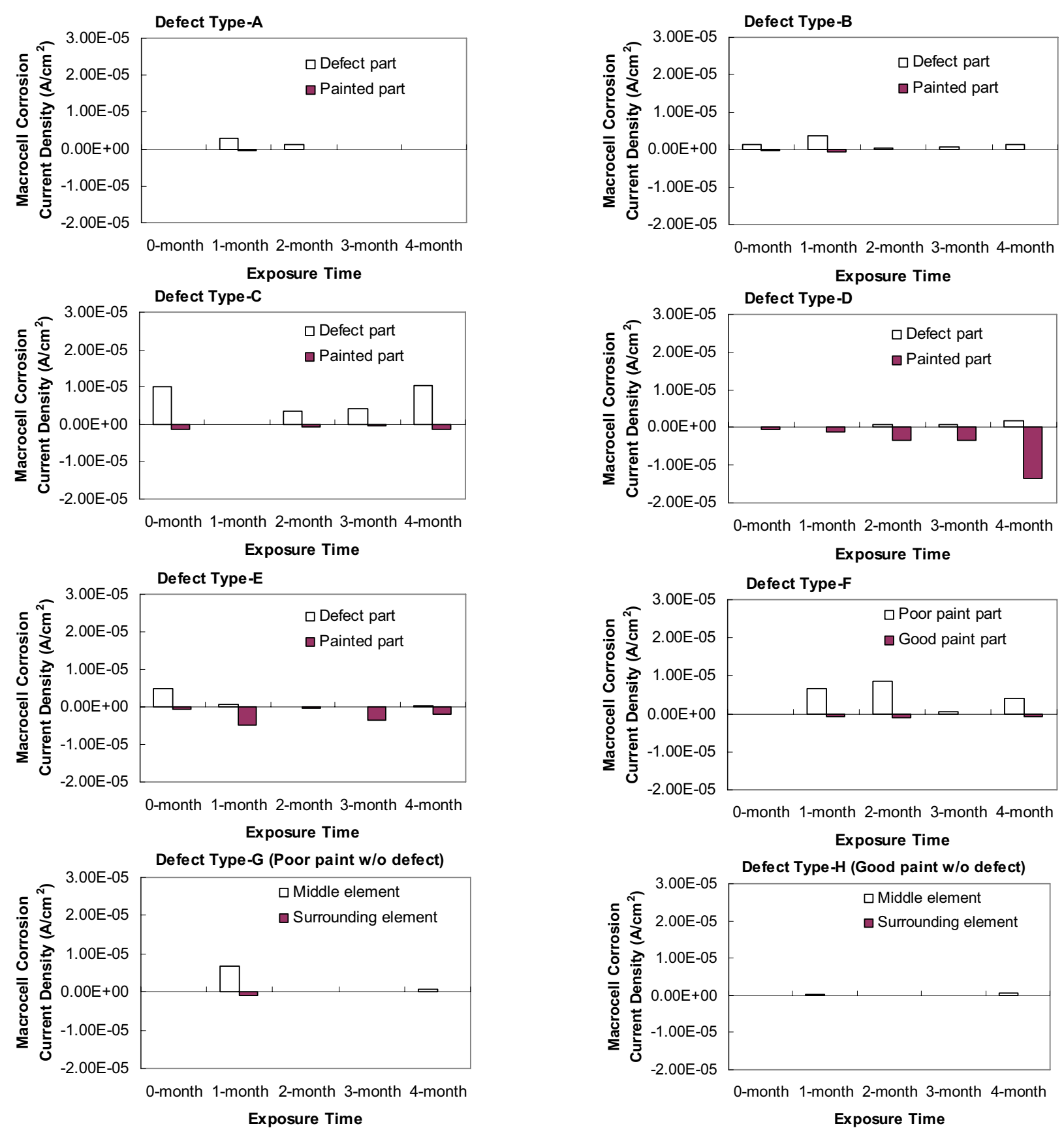

Fig. 7 Macrocell corrosion current density in specimens with different types of defects under submerged condition.

However, an opposite trend was observed for the specimens under the submerged condition. This particular result can be explained by the fact that as the temperature in the submerged condition was increased, the dissolved oxygen had a tendency to escape from the solution and therefore the dissolved oxygen (D.O.) content in the solution is decreased as shown in the figure which slowed down the corrosion reaction thus leading to lower values of macrocell and microcell corrosion.

It can also be observed that for all temperatures, the steel mass loss due to macrocell corrosion is lower than the steel mass loss contributed by microcell corrosion by one order of magnitude.

\section{(4) Estimation of macrocell corrosion rate in an existing paint coated structure}

In order to calculate the macrocell corrosion current between individual parts of the steel plate, a circuit diagram was constructed on the steel plate as shown in Fig. 11. The circuit analysis was done based on Ohm's law $(V=I R)$ and Kirchhoff's law (summation of current at any node is zero). The input data needed for the circuit analysis were halfcell potential, paint-solution resistance and polarization resistance. The setup for the measurement of these input data is the same as the one illustrated in Fig. 4. However, as an addition, the paint-solution resistance was determined as the resistance 

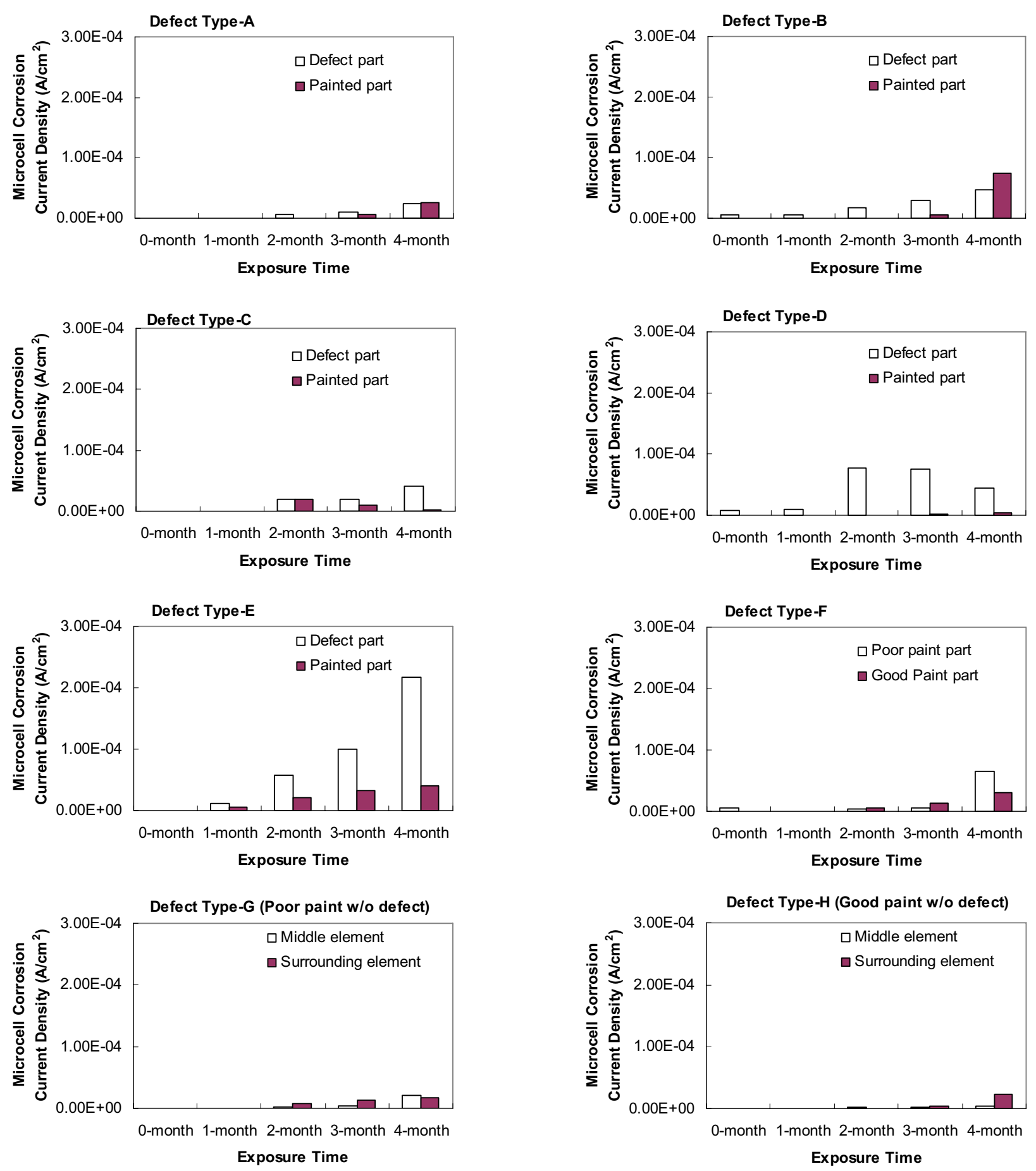

Fig. 8 Microcell corrosion current density in specimens with different types of defects under submerged condition.
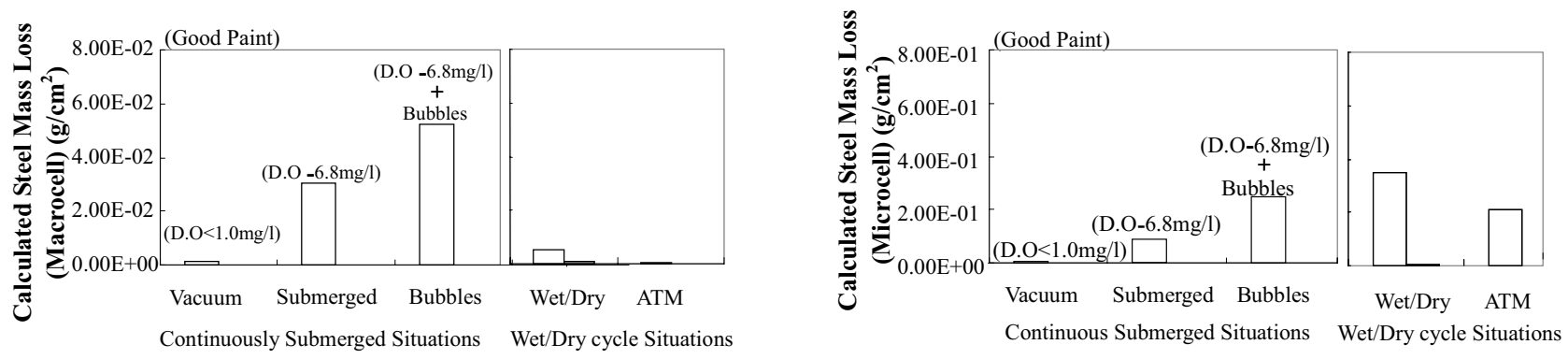

Fig. 9 Calculated steel mass loss by macrocell and microcell corrosion under different exposure situations. 

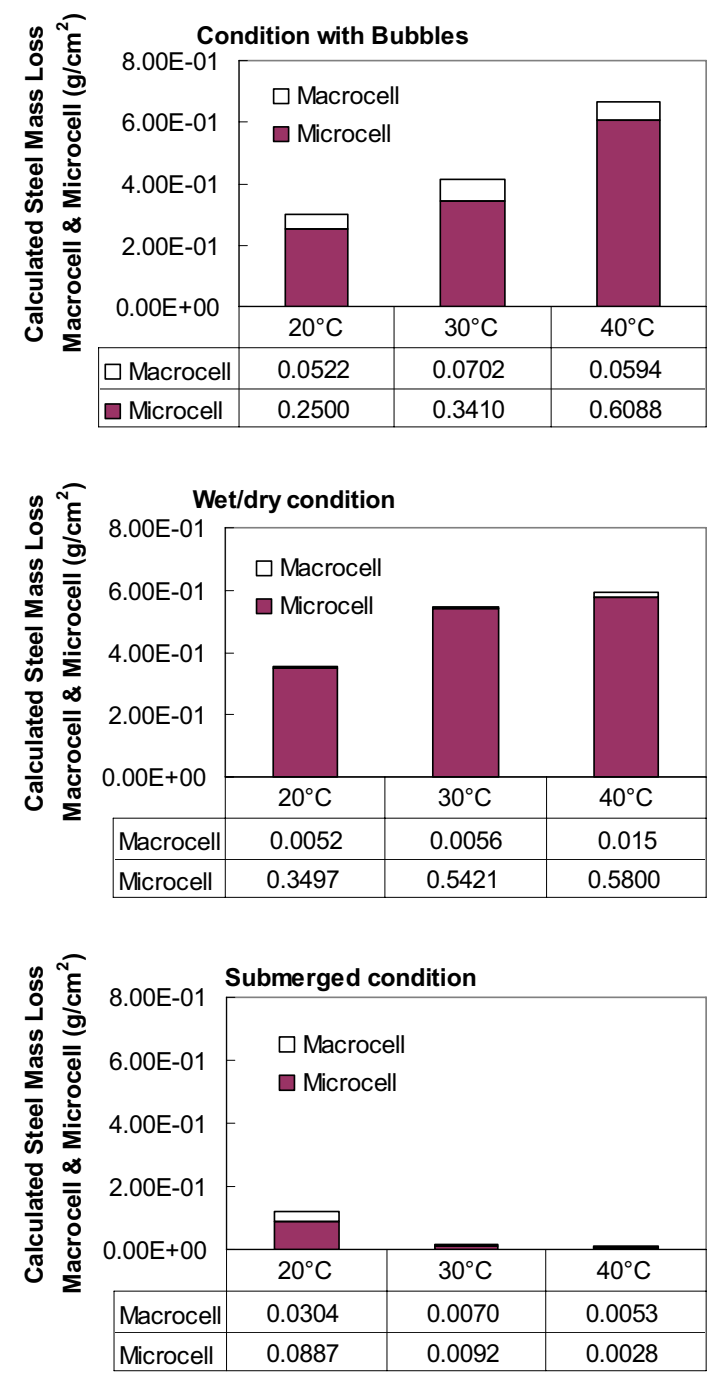

Fig. 10 Calculated steel mass loss at the defect by macrocell and microcell under different temperatures.

measured by the device under high frequencies. Generated simultaneous equations were then solved using a mathematics software (Mathematica 5.2 Student version).

Calculated values of macrocell current density based on the circuit model were compared with actual measured values as shown in Fig. 12. From the results, it was confirmed that the calculated values (Y-axis) had a good correlation with the measured values (X-axis) thus validating the method of using the proposed circuit model.

The validated circuit model was used to estimate macrocell corrosion in an existing structure. An existing steel structure (H-beam) located in Yokosuka, Japan was selected for performing a field measurement as shown in Fig. 13. The steel structure (30 years old), exposed to wetting and drying condition, was tar painted. The results of macrocell and microcell corrosion rates are shown in Fig. 14 and Fig. 15.

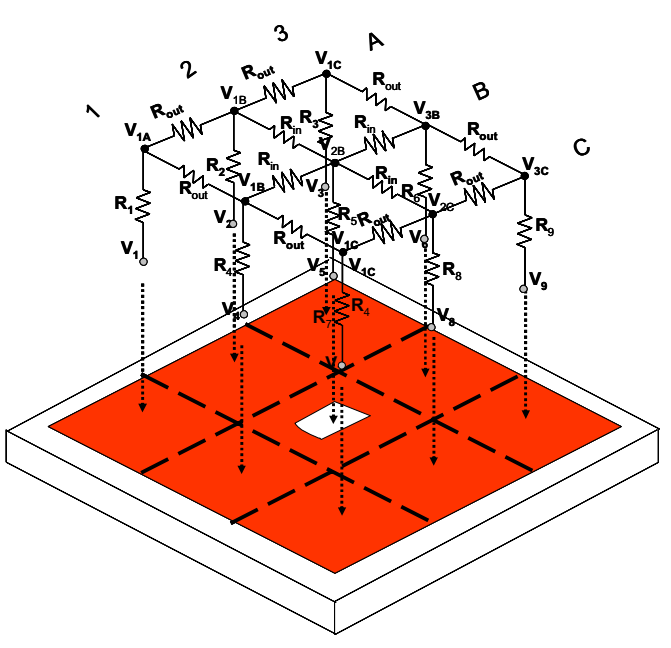

Fig. 11 Circuit diagram for a divided steel plate.

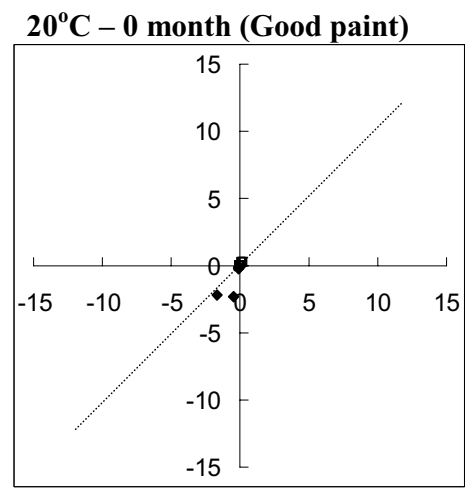

$20^{\circ} \mathrm{C}-2$ months (Good paint)

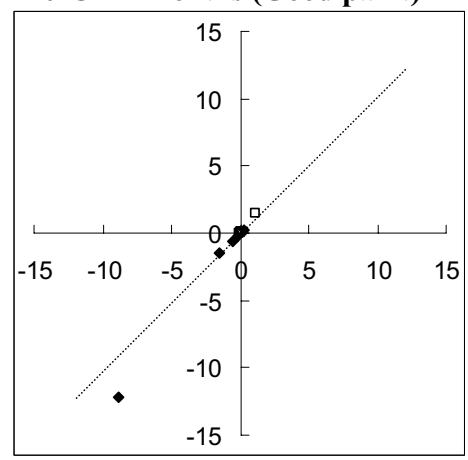

$20^{\circ} \mathrm{C}-4$ months (Good paint)

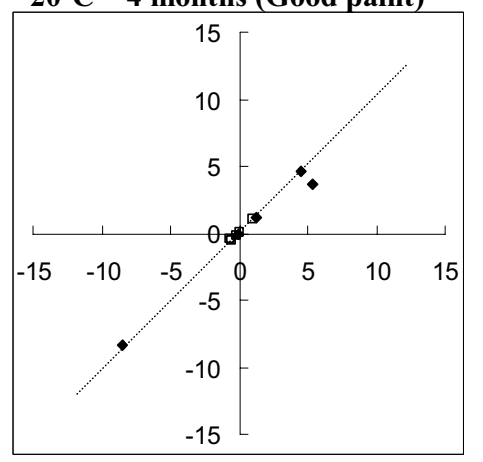

Fig. 12 Comparison of calculated current density values using the circuit model and measured values. 


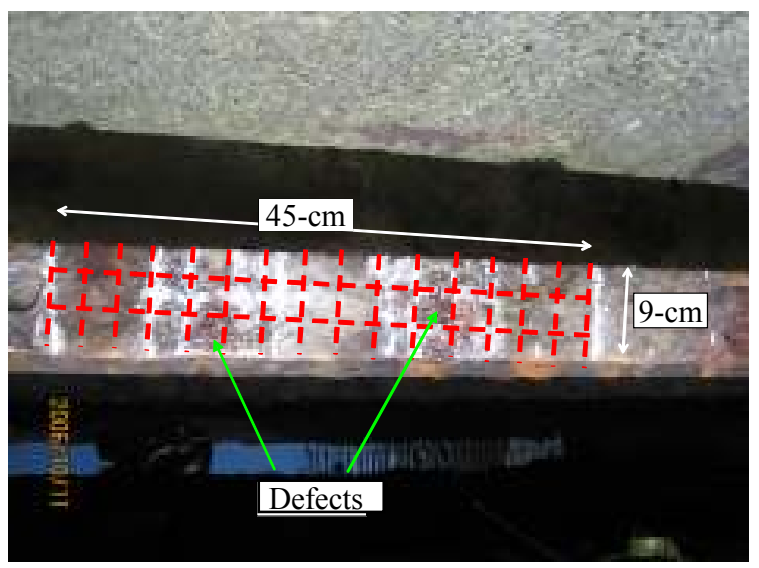

Fig. 13 Selected existing structure for estimation of macrocell corrosion.

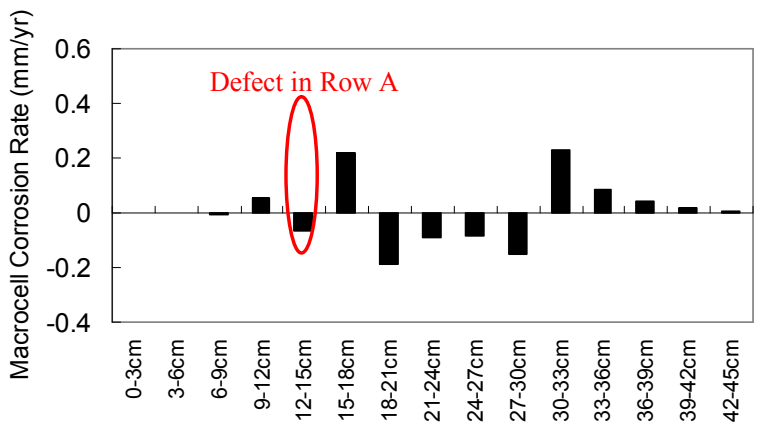

(a) Macrocell Corrosion Rates in Row A

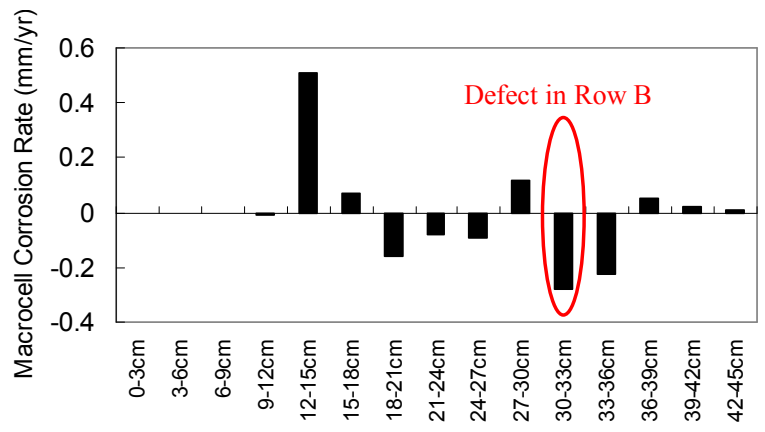

(b) Macrocell Corrosion Rates in Row B

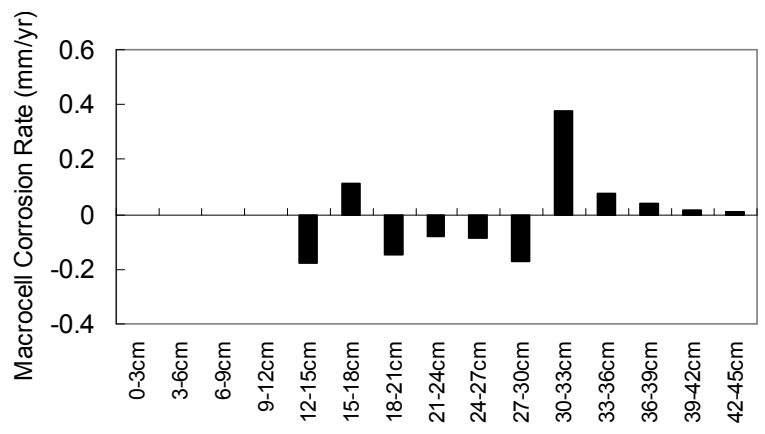

(c) Macrocell Corrosion Rates in Row C

Fig. 14 Estimated macrocell corrosion rates in an existing structure.

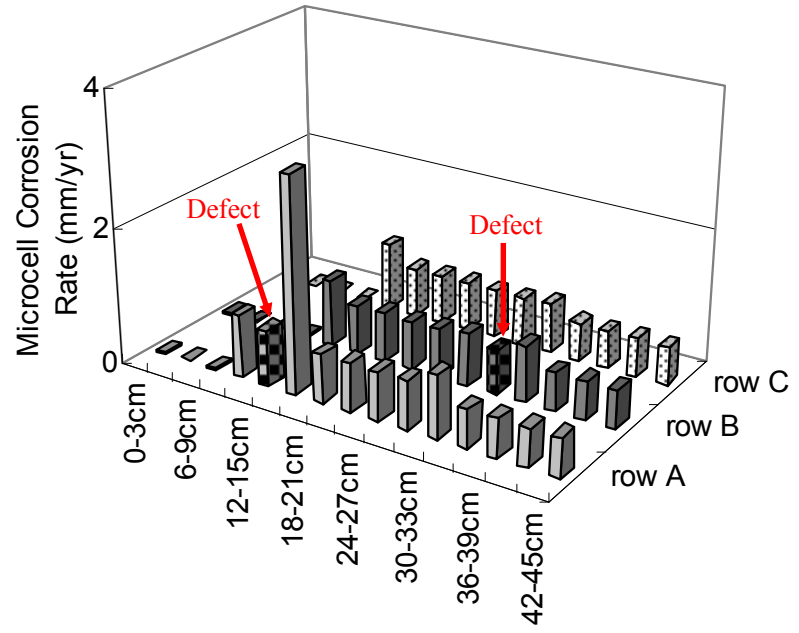

Fig. 15 Estimated microcell corrosion rates in an existing structure.

The results of macrocell corrosion rates show that the defect part of the existing structure already acted as cathode while the areas just next to the defect part showed highest macrocell corrosion rate. This behavior can be probably attributed to the fact that the structure was severely corroded thus the defect part was already filled and coated with layers of corrosion precipitates while the anodic portions have already expanded to the areas surrounding the defect. On the other hand, microcell corrosion rates are high not only on the defect part but also on the areas surrounding the defect because the paint coating throughout almost the entire structure was degraded thus microcell corrosion has occurred on the whole area of the structure. At this point it can be said that the corrosion rate of the existing structure was successfully estimated with the use of the circuit diagram.

\section{CONCLUSIONS}

(1) The divided steel plate evaluation method for macrocell corrosion of the steel plate was successfully proposed as experimental qualitative evidence show almost the same trend of polarization behavior in divided and undivided steel plates.

(2) It was confirmed that the macrocell corrosion occurred between the paint part and defect part, as the latter acted as anode and the former as cathode. The defect was the major cause of the corrosion of paint-coated steel.

(3) It was confirmed that the exposure situations and temperature greatly influenced the corrosion of paint-coated steel with defects. The condition where high dissolved oxygen is present provided the higher corrosion rates. As the temperature increased, the corrosion rates increased as well. 
However, the corrosion rate decreased in the condition where the supply of oxygen was reduced as the temperature was increased. Also, the contribution of microcell corrosion is higher than the macrocell corrosion by one order of magnitude.

(4) The estimation method for macrocell corrosion rate for an existing painted structure was successfully proposed. The proposed method was successfully applied in an existing structure.

ACKNOWLEDGMENT: The authors of this paper would like to extend their sincerest gratitude to the "Subcommittee on Corrosion Protection and Durability Evaluation of Steel and Composite Structures in the Marine Environment headed by Dr. Eiichi Watanabe, Professor Emeritus at Kyoto University)" of the JSCE Committee of Structural Engineering for the helpful and valuable discussions during the progress of the investigations done in this study.

\section{REFERENCES}

1) Fontana, M.: Corrosion Engineering, McGraw-Hill, 1978.

2) Smith, W.: Principles of Materials Science and Engineering $3^{\text {rd }}$ Ed., MacGraw-Hill, Inc., pp. 755-756, 1996.
3) Funke, W.: Mechanisms of Protecting Metals by Organic Coatings Against Corrosion, Proceedings of the Symposium on Corrosion Protection by Organic Coatings, The Electrochemical Society, Inc., Pennington, pp.1-10, 1987.

4) Haruyama, S., Asari, M., Tsuru, T.: Impedance Characteristics during Degradation of Coated Steel, Proceedings of the Symposium on Corrosion Protection by Organic Coatings, The Electrochemical Society, Pennington, pp. 197-207, 1987.

5) Loveday, D., Peterson, P., Rodgers, B.: Evaluation of Organic Coatings with Electrochemical Impedance Spectroscopy, JCT Coating Tech, www.coatingstech.org, 2004.

6) Scully, J.R., Hensley, S.T.: Lifetime Prediction for Organic Coatings on Steel and a Magnesium Alloy Using Electrochemical Impedance Methods, NACE Corrosion Journal, Vol.50, No.9, pp.705-716, 1994.

7) Min, A.K.: Fundamental Study of Measurement of Corrosion Rate in Paint Coated Steel Plates Exposed to Chloride Attacks, The 8th International Summer Symposium, JSCE, pp.259-262, 2006.

8) Miyazato, S., Otsuki, N., Kimura, H.: Estimation Method of Macrocell Corrosion Rate of Rebar in Existing Concrete Structures Using Non-destructive tests, East Asia-Pacific Conference (EASEC 8), 2, pp.531-542, 2001.

9) Tsuru, T., Maeda, R., Haruyama, S.: Applying of AC. method monitor to local corrosion, Technique of Corrosion Prevention, 28, pp.638-664, 1979.

(Received April 9, 2007) 